\title{
Když potenciálně rozvíjející situace nerozvijí: kritické didaktické incidenty v problémově orientované výuce ${ }^{1}$
}

\author{
Tereza ČešKová
}

\begin{abstract}
Abstrakt: Ukazuje se, že pro učitele jsou kompetence stále nesrozumitelné a ve výuce obtižně uchopitelné a že jejich rozvijeni u žákư je tím potenciálnè omezeno. Tato studie se zaméruje na kompetenci $k$ řèseni problémü, konkrétně pak na situace, které mají potenciál tuto kompetenci $u$ žákư rozvijet ( $t j$. na problémově orientované situace, v jejichž jádru stoji problémově orientované úlohy). To, že učitel ve výnce využije problémovè orientované učebni úlohy, automaticky neznamená, že tím u žákư kompetenci k résení problémů rozviji.

Cílem článku je proto popsat, co zpưsobuje, že prestože výnka obsahuje úlohy nesouci potenciál danou kompetenci rozvijet, tento potenciál neni využit.

Metody. Zkoumáno je 19 výnkových situací identifkkovaných v 10 vyučovacich hodinách prírodovédy, které stavěly na problémovè orientovaných úlohách, avšak zároveñ nebyly hodnoceny jako rozvijejici. Pomoci mikroanalytického prístupu metodou analýzy kritických didaktických incidentui jsou ukázány konkrétni podoby prüběhu problémovè orientovaných situaci ve výuce s cilem pojmenovat opakujici se jevy, kvůli nimž jejich potenciál neni využit.

Výsledky. Dominantni skupinou incidentư bylo prílišné vztahováni aktivity na učitele, které se projevovalo tím, že učitel natolik žáky provázel řešením úlohy, že ji de facto rěšil sám. Ve studii jsou podrobnè ukázány mechanismy, jak a za jakých okolností $k$ tomuto a dalšim incidentùm docházelo. Pojmenováni některých jevư, které oslabuji rozvijeni klícových kompetenci ve výuce, může pomoci ukázat, čeho se v praxi vyvarovat.
\end{abstract}

Kličová slova: kompetence $k$ řešení problémi̊, kritický incident, problémově orientovaná úloha, primárni vzděláváni, interakce.

Rozvíjení klíčových kompetencí je jedním z obecných cílů vzdělávání (RVP ZV, 2016). I kdyby aktuálně (ne)probíhající „revize“ RVP ZV skutečně přinesly obrat od normativního pojetí kompeten- cí k pojetí funkčnímu, gramotnostnímu, tak jak to naznačoval např. Fidrmuc (2018; podrobněji $\mathrm{k}$ různému chápání kompetencí a nekonzistentnosti v českém kurikulu in Češková, 2020b), stále

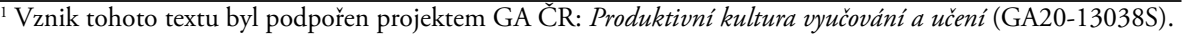


budou jedním z hlavních cílů vzdělávání. Zároveň se ale ukazuje, že pro učitele jsou kompetence stále nesrozumitelné a obtížně uchopitelné a že jejich rozvíjení u žáků je tím potenciálně ohroženo či omezeno (Analýza, 2018, s. 6). Tato studie se zaměřuje na kompetenci $\mathrm{k}$ řešení problémů, konkrétně pak na výukové situace, které mají potenciál tuto kompetenci u žáků rozvíjet, a to na příkladu přírodovědného učiva na prvním stupni. Vzdělávací oblast Člověk a jeho svět, na kterou byla zaměřena sledovaná výuka, je orientovaná na praktický život a pochopení světa kolem nás, staví na souvislostech a integruje obsahy různých oborů, uči žáky „všímat si podstatných věcných stránek" atd. (srov. RVP ZV, 2016, s. 42). Poskytuje tak vhodnou prríležitost $\mathrm{k}$ rozvíjení kompetence $\mathrm{k}$ řešení problémů, nebot toto jsou zároveň základní charakteristiky problémově orientované výuky, pomocí níž lze danou kompetenci rozvíjet. Základem problémově orientované výuky jsou problémově orientované úlohy. ${ }^{2}$

$\mathrm{V}$ našem předchozím výzkumu jsme popsali, ${ }^{3}$ že prŕležitosti k rozvíjení kompetence $\mathrm{k}$ řešení problémů lze žákům zprostředkovávat skrze problémově orientovanou výuku, co jsou problémově orientované úlohy, jak jsou zasazeny do výukových situací (Češková, 2016) a jakou podobu má řešení těchto úloh v kontextu výukových situací - tedy jaké fáze tohoto procesu byly ve sledovaných hodinách využity a jakým způsobem (Češková \& Knecht, 2016). Ukázalo se, že to, že učitel ve výuce využije problémově orientované učební úlohy, automaticky neznamená, že tím rozvíjí u žáků kompetenci $\mathrm{k}$ řešení problémů. $Z$ výzkumu tudíž vyplynula potřeba zaměřit se na samotný průběh řešení takových úloh - na interakci při řešení problémově orientovaných úloh. Bylo nutné nejdříve vymezit, jak vypadají interakce $\mathrm{v}$ situacích potenciálně kvalitních (Češková, 2020a), a popsat tak žádoucí podobu (klíčové charakteristiky) výukové situace založené na problémově orientované úloze, které potenciálně př̀ispívají k tomu, že úloha rozvíjí kompetenci k řešení problémů. Cílem tohoto článku je popsat, co způsobuje, že ve výuce obsahující úlohy nesoucí potenciál danou kompetenci rozvíjet tento potenciál není využit. Smyslem je pojmenovat některé možné příčiny a pomoci tak v důsledku s poznáním, čeho se vyvarovat, aby obsahově zaměřená výuka (srov. Janík et al., 2013), jež v sobě ohled na kompetence nese, kompetence skutečně mohla rozvíjet. Nabízí se úvaha, že by stačilo popsat nedostatky, kvůli nimž jsme sledované situace nezařadili do vzorku potenciálně kvalitních situací. Takový postup by však přinesl př́iliš povrchní poznání. V prezentované

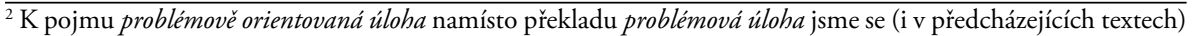
přiklonili z důvodu české konotace problému jako něčeho špatného či nežádoucího, což neodpovídá povaze problému jakožto jádru úloh, které jsou hodnotné právě díky němu. Př́vlastek problémově orientovaná podle našeho názoru lépe vystihuje, že jde o úlohu, která není nežádoucí, nýbrž která problému využívá jako př́ležitosti. ${ }^{3}$ Jelikož prezentovaná studie navazuje na studii publikovanou ve spoluautorství, jsou pasáže, v nichž je na tuto část odkazováno, psány v plurále. V ostatních částech je uživán singulár.
} 
studii je využita cesta mikroanalýz zkoumajících interakci během řešení problémově orientovaných úloh, $\mathrm{k}$ níž - jako k zatím nedostatečně probádané - vyzývají v souvislosti s problémově orientovanou výukou Rotgans a Schmidt (2019).

\section{Situace PotenciálNĚ ROZVÍJEJÍCÍ KOMPETENCI K ŘEŠENÍ PROBLÉMÙ}

Rozvíjení kompetence $\mathrm{k}$ řešení problémů ve výuce může probíhat dvěma způsoby - bud' skrze úlohy, které přímo cílí na danou kompetenci, ale právě pro tuto zaměřenost nedbají tolik na oborový obsah; nebo skrze problémově orientované situace zaměřené primárně na obsah, který je ale zprostředkovaný tak, že zároveň danou kompetenci rozvíjí. Ve své studii se držím druhého přístupu, který se ve výuce objevuje pro své obsahové zaměření častěji, a sleduji situace, $v$ jejichž jádru stojí problémově orientovaná úloha (dále PO úloha).

V hledání situací rozvíjejících kompetenci $\mathrm{k}$ řešení problémů vycházím (a) $\mathrm{z}$ řešení problémů (problem solving; viz zejména Jonassen, 2011; Sternberg, 2009), z něhož přebírám především vymezení neúplně strukturovaného problému jakožto základu problémově orientované úlohy; a (b) z problémově orientovaného učení (problem-based learning, dále PBL; Barrows, 1996; nejnověji Moallem, Hung \& Dabbagh, 2019). PBL staví na problému z reálného světa, jenž potřebuje vysvětlení, podložení teorií, odhalení me- chanismu, principu či procesu (Schmidt, Rotgans, \& Yew, 2019, s. 26), a je považováno za vysoce efektivní výukový přístup, a to i ve výuce (prrírodních věd) na prvním stupni (Rotgans \& Schmidt, 2019). Z PBL přebírám hlavní zásady a postup řešení.

$\mathrm{V}$ souladu s popsanými východisky za PO úlohu považuji takovou úlohu, která: 1. obsahuje neúplně strukturovaný problém, 2. umožňuje více řešení (i když učitel očekává nějakou odpověd', vede k ní více alternativních myšlenkových operací nebo existuje více správných řešení) a zároveň splňuje alespoň dvě z následujících charakteristik: 3. mezioborový charakter (vyžaduje tedy užití souvislostí z různých kontextů), 4. učitel je v ní pouze zadavatelem úlohy (konstruktivistický charakter, větší aktivita je na straně žáka), 5. vychází z reálného života či ze zkušenosti žáků, 6. je řešena ve skupině (řešení je založeno na sociokognitivním dialogu). Ideální situace, $v$ níž je $P O$ úloha řešena, pak má následující fáze: F1 - iniciování PO úlohy, F2 - analyzování PO úlohy, F3 - vyhledávání informací, $\mathrm{F} 4$ - syntetizování výsledků/řešení, F5 - sumarizování výsledků/ řešení, F6 - prezentování výsledků/řešení, F7 - reflektování procesu řešení (viz např. Barrows \& Tamblyn, 1980; Delisle, 1997; Savin-Baden \& Howell Major, 2004; Etherington, 2011, aj.; výchozím teoriím je věnována studie Češkové, 2016). Za potenciálně rozvíjející PO situace s ohledem na konstruktivismus a důraz na geneticko-sokratovské postupy coby znak kvalitní výuky z hlediska procesu didaktické transformace (viz Klieme, Schümer \& 
Knoll, 2001, s. 51) považuji ty PO situace, v nichž byla žáky aktivně řešena PO úloha, tedy v nichž je větší prostor věnován fázím, které se týkají vlastního řešení PO úlohy (podrobný popis výběru viz kap. 3 této studie).

Vymezení fází tak, jak je v literatuře popisováno, nám poskytne náhled na postup řešení. Z předchozího zkoumání (viz Češková \& Knecht, 2016) je však zřetelné, že pouhé zařazení $\mathrm{PO}$ úlohy, resp. přítomnost jednotlivých fází řešení nezaručí, že $\mathrm{k}$ rozvíjení dané kompetence skutečně dochází a že je nutné se v řešení PO úloh ve výuce zaměřit na samotnou interakci. $\mathrm{V}$ interakci při řešení PO situací je zřetelná změna učitelovy role - spíše než jako někdo, kdo zná odpověd', je tím, kdo koriguje žáky při hledání řešení; spíše než jako někdo, kdo opravuje chybu, se stává tím, kdo žáky přiměje či přivede $\mathrm{k}$ nalezení správné odpovědi, a spíše než jako ten, kdo se ptá konkrétně, se posouvá do role toho, jenž radí v řešení co možná nejméně a nechává tak co nejvíce prostoru pro přemýšlení žáků (viz Češková, 2020a). Následující diagram (obr. 1) popisuje potenciálně rozvíjející situace podrobněji.

Uvedený způsob není samozřejmě jediný možný, z množství prostředků, které může učitel použít, je patrná variabilita situací. V edukační realitě ani není možné, aby byl beze zbytku praktikován. Je spíše oním (nedostižným) ideálem, $\mathrm{k}$ němuž směřujeme. Neustálé porovnávání s ním pak může pomoci se $\mathrm{k}$ němu přibližit a praxi tak zlepšit - srov. Strouhal (2014). Uvedený popis tak směřuje spíše $\mathrm{k}$ principiálnímu př́ikladu a slouží jako teoretické vymezení, které rámuje $\mathrm{PO}$ výukové situace a $\mathrm{k}$ němuž se budu ve svém výzkumu vztahovat. Hledáním odpovědi na otáz$\mathrm{ku}$, proč nebyl dostatečně využit potenciál situací, jež stály na PO úloze, můžeme zároveň částečně tato „pravidla“ verifikovat (viz Tripp, 2012, s. 36). K tomu bude využita metoda analýzy kritického didaktického incidentu.

\section{METODA KRITICKÉHO (DIDAKTICKÉHO) INCIDENTU}

Metoda analýzy kritického incidentu (critical incident technique; v české literatuře též metodika klíčových didaktických událostí - viz Slavík et al., 2017, s. 281-288) je kvalitativní př́stup, jenž staví na sběru a analýze př́íkladů určité aktivity, umožňuje tak identifikovat podobnosti, odlišnosti a vzorce a zároveň získat vhled to toho, jak a proč jsou účastníci $\mathrm{v}$ této aktivitě zapojeni. Smyslem je utř́dit kritické incidenty (critical incident; dále KI) a identifikovat kritické chování (critical behaviors; Hughes, 2007). Autor metody Flanagan považuje za incident ,jakoukoli činnost, která je dostatečně uzavřená na to, aby bylo možné usuzovat na její následky" (1954, nestr.). Kritický incident je pak překvapivý nebo problematický moment, $\mathrm{v}$ jehož důsledku dojde ke změně v očekávané efektivitě nebo k předpokládanému úspěchu dané činnosti (srov. Angelides, 2001, s. 430; Thuynsma, 2001, in Bruster \& Peterson, 2013, s. 172). Jeho určení je založené na interpretaci významu události (Tripp, 2012, s. 8) a při jeho vyhledání záleží na individuálním způsobu 


\section{Zadání PO úlohy}

- Neadresné (učitel nevyvolává konkrétní žáky).

- Kontrola porozumění.

- Objasnění potenciálně neznámých pojmů ze zadání.

- Parafrázování zadání.

\section{几}

\section{Průběh řešení PO úlohy}

- Volnější pravidla - žáci hovoří bez vyvolávání, reagují na sebe navzájem, doplňují se, podporují i rozporují.

- Na řešení je dán delší čas, prostor je dán i žákům, kteří se sami nezapojí.

- Učitel do interakce zasahuje:

a) radou či nápovědou - důležité je, že řešení neprozrazuje, ale snaží se k němu žáky přivést, neradí víc, než je nezbytně nutné, ne tak, že by žáky navedl přímo k řešení, spíše zopakuje či zdůrazní již řečené, podstatné jevy, které jsou klíčové pro řešení apod.:

- zúžením problémového prostoru (kde začít, snížením počtu možných operací, jež lze k řešení využít; radou, jaký didaktický prostředek využít, atp.) - obvykle nejdříve radí obecně, následuje otázka po zdůvodnění a třetí otázkou se posune ke konkrétnímu jevu,

- využitím kontextu (srovnáním, naznačením souvislostí s něčím žákům známým, připodobněním $\mathrm{k}$ jevu v jiném kontextu),

- modelováním (nápověda napodobováním nebo předváděním jevu);

b) dostanou-li se žáci mimo téma (např. vlivem podúloh nutných k vyřešení PO úloh), zopakuje nebo parafrázuje původní otázku, zcela scestné odpovědi obvykle nereflektuje;

c) v případě, že se diskuse vymkne z pořádku a žáci se překřikují.

- Zpětná vazba je prováděna obvyklými prostředky, lišit se může obsah, a to zejména častějším rámcovým označením chyby (tedy nikoli přesným) a tím, že učitelé nikdy nereagují na žákovu špatnou odpověd’ tím, že sami řeknou správnou, naopak základem jsou otázky, v nichž učitel elicituje:

- zpřesnění žákovy odpovědi - ptá se po dovysvětlení, příčině, zdůvodnění, doplnění odpovědi nebo výběru podstatného; otázka Proč? je „meritem věci“;

- více odpovědí a hledá více možných řešení.

\section{ח}

\section{Odpověd/ř̌̌̌ení}

- Doplnění, rozvinutí řešení, usazení do širšího kontextu.

- Shrnutí a zexplicitnění nové znalosti či vyvození nového pojmu. ${ }^{4}$

Obr. 1. Charakteristiky potenciálně rozvíjejících PO výukových situací během fází orientovaných na vlastní řešení PO úloh (podle Češková, 2020a)

\footnotetext{
${ }^{4} \mathrm{~V}$ popisu není nijak zohledněna reflexe procesu řešení (tedy F7), a to proto, že se ve sledovaném vzorku neobjevila ani jednou. To ale neznamená, že do ideálního průběhu řešení nepatř́i.
} 
nazírání na danou situaci. Už samo označení nějakého momentu (části situace) kritickým incidentem značí, že mu přisuzujeme určitý význam. Jak Tripp (tamtéž) upozorňuje, můžeme vlastně cokoli, co se stane, $\mathrm{z}$ nějakého úhlu pohledu posuzovat kriticky, avšak teprve po podrobnějším prozkoumání můžeme říci, že incident lze považovat za zásadní - kritický. Incidenty jsou běžnou součástí výuky, ale teprve naše interpretace události přikládá důležitost, význam. $\mathrm{V}$ pedagogickém kontextu může být kritický incident součástí profesionální reflexe (tamtéž, s. 24), a o to se také pokusím v této studii.

Metoda se už od počátku rozvíjela v souvislosti s výzkumem výuky. Její začátky se datují do období 2 . světové války, kdy byla využívána při výcviku pilotů (nejprve za účelem zjištění, v čem bojoví piloti „selhávají“ - viz Flanagan, 1954, srov. Butterfield et al., 2005). Od 90. let minulého století začala být hojněji využívána i v základním pedagogickém výzkumu, a to $\mathrm{v}$ oblasti reflexe $-\mathrm{z}$ novějších ${ }^{5}$ výzkumů např. pro zkoumání KI na praxi studentů učitelství matematiky (Goodell, 2006), ke zkoumání reflektivní praxe u studentů učitelství (Bruster \& Petersen, 2012; Harrison \& Lee, 2011; Francis, 1997 , ad.). KI je využíván např. při propojení teorie a praxe při rozhovorech studentů s jejich cvičnými učiteli (Lister \& Crisp, 2007), jako metoda pro analýzu výukové praxe učitelů (Hole \& McEntee, 2003) či jako prostředek pro formativní hodnocení praxe studentů (Davies \& Kinloch, 2000).

Ačkoli je metoda nejčastěji využívána k reflektování vlastní praxe participantů na základě rozhovorů nebo zápisků z praxe, její uplatnění bylo modifikováno i v souvislosti s didaktickým zaměřením. Díky své podstatě v teoretickém ukotvení dává metoda př́ležitost i $\mathrm{k}$ hodnocení situace $\mathrm{z}$ pozice nezúčastněného pozorovatele. Na základě pozorování jsou v takovém př́padě pomocí obdobného postupu jako u KI analyzovány kritické didaktické incidenty (critical didactic incidents, dále $\mathrm{KDI}$ ), což jsou kritické momenty, jež vznikají během zprostředkování obsahů výuky (Amade-Escot, 2005, s. 127). Tento př́stup můžeme sledovat např. v kontextu rozvíjení didaktických znalostí obsahu $\mathrm{v}$ př́rodovědném vzdělávání u studentů učitelství pro 1. stupeň (Hanuscin, 2013), ve zkoumání vnímání interakce ve výuce během řešení matematických úloh u budoucích učitelů matematiky (Potari et al., 2011) či v tělovýchovně orientovaném výzkumu zabývajícím se výukou techniky lezení (Hennings, Wallhead \& Byra, 2010). Jak ukázal např. výzkum Griffinové (2003), využití techniky kritického incidentu vede $\mathrm{k}$ lepšímu všímání si, otevřenosti, reflektivnosti a zodpovědnosti. Situace, v nichž došlo ke KDI, mají podle Slavíka a kol. (2017, s. 284) největší potenciál pro zlepšení, nebot́ právě v nich dochází k nejvýraznějšímu nesouladu mezi obsahem, cíli, metodickým postupem a žákovskou zkušeností i motivací k učení.

${ }_{5}^{5}$ Pro přehled starších pedagogických výzkumů využívajících KI viz Amade-Escot (2005). 
Tab. 1. Přehled identifikovaných problémově orientovaných výukových situací

\begin{tabular}{|c|c|c|c|c|}
\hline $\begin{array}{l}\text { Vyučovací } \\
\text { hodina }\end{array}$ & $\begin{array}{c}\text { PO situace } \\
\text { pro analýzu KDI }\end{array}$ & $\begin{array}{c}\text { Celkem PO } \\
\text { situací } \\
\text { u učitele }\end{array}$ & $\begin{array}{c}\text { Doba strávená PO } \\
\text { situacemi } \\
\text { (\% z celkové doby } \\
\text { výuky) }\end{array}$ & $\begin{array}{c}\text { Doba strávená PO } \\
\text { situacemi zahrnutými } \\
\text { do analýzy KDI } \\
\text { (\% z celkové doby PO } \\
\text { výuky) }\end{array}$ \\
\hline $\mathrm{A} 1$ & $\mathrm{~S} 2$ & \multirow{2}{*}{8} & \multirow{2}{*}{$19: 16(21 \%)$} & \multirow{2}{*}{ 7:36 (39\%) } \\
\hline $\mathrm{A} 2$ & S3, S5, S6 & & & \\
\hline B1 & S9, S10 & \multirow{2}{*}{3} & \multirow{2}{*}{$02: 21(3 \%)$} & \multirow{2}{*}{ 1:54 (81\%) } \\
\hline B2 & S11 & & & \\
\hline $\mathrm{C} 1$ & S16 & \multirow{2}{*}{9} & \multirow{2}{*}{$37: 50(42 \%)$} & \multirow{2}{*}{$7: 40(20 \%)$} \\
\hline $\mathrm{C} 2$ & S18, S19 & & & \\
\hline D1 & S21, S22 & \multirow{2}{*}{6} & \multirow{2}{*}{$30: 35(31 \%)$} & \multirow{2}{*}{$29: 03(95 \%)$} \\
\hline D2 & $\mathrm{S} 24, \mathrm{~S} 25, \mathrm{~S} 26$ & & & \\
\hline E1 & & \multirow{2}{*}{5} & \multirow{2}{*}{$15: 03(17 \%)$} & \multirow{2}{*}{$13: 28(89 \%)$} \\
\hline $\mathrm{E} 2$ & S28, S29, S30, S31 & & & \\
\hline
\end{tabular}

Pozn.: A-E označují jednotlivé učitele, číslo pak znamená, ve které hodině se situace odehrála; $S$ znamená situaci a číslo pořadí problémově orientované situace v celém vzorku.

Proto považuji metodu za vhodný nástroj ke zkoumání situací, které mají jistý potenciál, avšak není využit.

Níže popísí realizovaný postup analýzy KDI, který vychází z původního postupu rozvinutého v 50. letech Flanaganem, doplněného a upraveného $\mathrm{v}$ inspiraci Hughesovou (2007) tak, aby odpovídal stávajícím nárokům na výzkumné studie a také aby zohlednil, že nejde o hodnocení vlastní výuky výzkumníka. Design a principy zůstávají zachovány, mění se pouze částečně perspektiva nahližzení na sledovanou situaci s ohledem na výzkumný vzorek a sledovaný cíl.

\section{VÝZKUMNÝ VZOREK A POSTUP ANALÝZY}

Výzkumný vzorek tvořilo 10 hodin př́rodovědy na 1 . stupni ZŠ (resp. Člověk a jeho svět), natočených $\mathrm{v}$ roce 2011 jako součást IVŠV videostudie u pěti náhodně vybraných učitelů, ve dvou po sobě jdoucích vyučovacích hodinách u každého. Učitelé neměli žádné zadání, naopak, hodiny měly být co nejobvyklejší, ${ }^{6}$ což je vhodné ze dvou důvodů - jednak by se rozvíjení kompetencí mělo prolínat napříc celým kurikulem a záměrem bylo nahližet na běžnou výuku, jednak

\footnotetext{
${ }^{6} \mathrm{Na}$ základě dotazníků autentičnosti (viz Najvar et al., 2011) lze konstatovat, že sledovaní učitelé hodnotili výuku jako podobnou svým obvyklým hodinám a její průběh jako typický.
} 
nebylo smyslem zkoušet učitele, nakolik něco „umí“. V našem vzorku bylo identifikováno 41 problémově orientovaných úloh (dále PO úloh), jež byly soustředěny v 31 problémově orientovaných výukových situacích (dále PO situacích). $\mathrm{V}$ každé z nich jsme pak analyzovali fáze řešení PO situace (viz Češková \& Knecht, 2016) a z nich vybrali potenciálně kvalitnější $(\mathrm{N}=12)$, resp. rozvíjející (srov. Janík et al., 2013; viz výše). ${ }^{7}$ Předmětem této studie je analýza těch PO situací, u nichž byl identifikován potenciál, který ale ve sledované situaci nebyl využit ( $\mathrm{N}=19$; viz tab. 1).

Cílem studie je u všech PO situací, které nejsou rozvíjející, analyzovat kritické didaktické incidenty. Základní výzkumná otázka zní: Co zpưsobuje, že navzdory nastoleni problémovè orientované úlohy ve výuce jeji potenciál neni zcela využit? Analyzovány jsou záznamy jednotlivých hodin a jejich doslovné transkripty. Studie tedy zachycuje náhled toho, co lze ve výuce pozorovat, nikoli to, co učitel zamýšlel, a jde v ní o průběh situace, nikoli o to, jak o ní učitel uvažoval. Tato perspektiva je sice přiznaným limitem výzkumu, přináší však př́ležitost analyzovat situace s odstupem. Zároveň ale již Flanagan (1954) upozorňuje, že K(D)I může pozorovatel shledat pouze $\mathrm{v}$ situaci, u níž je dostatečně zřejmý její záměr či cíl. Při vysvětlení a zdůvodnění jevu je nutné vzít v úvahu (pozorovatelný) kontext, celý proces je tedy výraznou interpretací výzkumníka. S tím se lze vyrovnat důsledným porovnáváním analyzovaných jevů $s$ teorií na pozadí, která umožní zaujmout $\mathrm{k}$ popisovanému jevu určitý (i hodnoticí) postoj (srov. Tripp, 2012, s. 25)..$^{8}$ Současně vycházím z toho, že je-li nějaká problémově orientovaná úloha ve výuce učitelem položena, není její problémově orientovaná formulace náhodná.

$\mathrm{Na}$ začátku bylo třeba vymezit, co bude považováno za KDI. Při analýze KDI vždy hledáme kontextualizované př́klady, proto za KDI byla považována část situace, $\mathrm{v}$ níž se ztrácí potenciál rozvíjet kompetenci $\mathrm{k}$ řešení problémů, při současném ohledu na kontext celé situace. $\mathrm{V}$ analýze tedy nebyly zahrnuty části situací, které KDI předcházely, a to ani v př́padě, že $\mathrm{v}$ nich interakce neproběhla optimálně. Analyzovány byly až ty části, $\mathrm{v}$ nichž řešení ztratilo potenciál rozvíjet kompetenci $\mathrm{k}$ řešení problémů, který do té doby situace nesla. Vždy šlo o incidenty vztahující se $\mathrm{k}$ řešení PO situace, nikoli např̀ o přerušení jejího řešení kvůli organizačním či jiným záležitostem.

\footnotetext{
${ }_{7}$ Za rozvíjející situace byly považovány ty PO situace, které věnují větší část svého času fázím orientovaným na vlastní řešení PO úlohy (tedy fáze F2 - analyzování PO úlohy, F3 - vyhledávání informací, F4 - syntetizování výsledků/řešení a F7 - reflektování procesu řešení); a F5 - sumarizování výsledků/řešení za podmínky, že trvala kratší dobu, než součet fází $2,3,4$ a 7 , tedy tehdy, když převažovalo řešení PO úlohy, v němž větší iniciativa byla ponechána žákům než učiteli při sumarizování.

${ }^{8}$ V souladu s doporučeními Maxwella (2010, s. 282-286) a Cohena, Maniona a Morrisona (2011, s. 181-185) byly využity postupy, jakými je možné subjektivitu minimalizovat (porovnávání s výchozí teorií, opakovaná pozorování, podrobná popisování a analyzování videozáznamů a doslovných transkriptů, podrobný, kontextuální popis př́ípadů - v tomto př́ípadě výukových situací -, dokládání výňatky z dat).
} 
$\mathrm{K}$ analýze bylo využito dvou prístupů - hledání tzv. ne-událostí (non-events) a atypických momentü (atypical events). Ne-událostmi označujeme moment, který ne-nastal. Tripp (2012, s. 44) je doporučuje jako označení toho, co se ne-stalo - pokud se něco v situaci odehrálo, znamená to, že něco jiného, často žádoucího, se naopak neodehrálo. A naopak, označením toho, co se neodehrálo, můžeme poukázat na něco, co se odehrálo. Navíc nestačí ptát se, co se nestalo, ale také proč se to nestalo. $\mathrm{U}$ atypických incidentů jsem postupovala opačně - hledala jsem, co způsobilo, že se situace nevyvinula rozvíjejícím způsobem (srov. tamtéž, s. 36), nebot' atypické momenty jsou ty, které mohly způsobit, že se řešení neodvíjelo jako typické, čili to, co se v události neděje oproti očekávatelnému průběhu, nebo naopak, co se v ní děje, ale není to z hlediska rozvíjení dané kompetence žádoucí (srov. tamtéž, s. 36). Z využití těchto dvou př́stupů vzešly následující otázky pro popis jevů: Co je ve sledované situaci obvyklé? Co je specifické? Co vede ke stanovenému cíli (z hlediska rozvijeni kompetence $k$ řešeni problémü)? Co se v situaci nedèje, $i$ když by to bylo vzhledem $k$ řešeni PO úlohy žádoucí? Proč se to neděje? Co bylo výsledkem KDI??

Vlastní analýza dat (viz Tripp, 2012, s. 69-75; Flanagan, 1954) musí být systematická, záměrná a zaměřená (s jasným cílem), aby bylo možné odlišit důležité od nedůležitého, posoudit realizované na základě ideálního atp., dopředu je nutné určit, pro jaký účel je vytvořena. Záro- veň však předložený postup nemá podle obou autorů být rigidním návodem, spíše sadou principů, které je vhodné adaptovat a modifikovat směrem $\mathrm{k}$ co nejlepšímu uchopení zkoumaných situací. Předložená analýza tak probíhala podle doporučení jmenovaných autorů skrze opakované vztahování analyzovaných jevů (viz postup výše) $\mathrm{k}$ teoretickému rámci a následné hledání pravidelností, jež nakonec vyústilo $\mathrm{v}$ uspořádání KDI do kategorií několika úrovní: od obecných rámců přes specifičtější induktivně vytvořené kategorie (viz podkapitoly výsledků) po odlišení úrovní uvnitř těchto kategorií. Během analýzy docházelo $\mathrm{k}$ neustálému přezkoumávání KDI, upravování a redefinování kategorií i subkategorií, resp. opakujících se témat. Cílem bylo sdružovat data a nacházet podobnosti, odlišnosti a vzorce, které povedou k pochopení jevu. Flanagan zdůrazňuje, že neexistuje žádný minimální počet zahrnutých incidentů, ale že jde o jejich kvalitu a nasycenost dat. Výzkumné sdělení pak musí být zakotveno $v$ datech, směřuje $\mathrm{k}$ obecnějším poznatkům a doporučením vztahujícím se $\mathrm{k}$ typově podobným prípadům. $\mathrm{O}$ to se pokusím v následující kapitole.

\section{VÝSLEDKY}

Výsledky představím ve dvou částech. Každá z nich popisuje jednu kategorii sdružující typově podobné kritické didaktické incidenty.

\footnotetext{
${ }^{9}$ Př́stupy $\mathrm{k}$ analýze dat spojované $s \mathrm{KI}$ jsou rozmanité - Mohammedová (2016) kupř. začala pozitivy, negativy a zajímavostmi, které sledované situace přinesla, Hughesová (2007) hodnocením, co bylo efektivní, a co ne.
} 


\subsection{Když učitel „nevydrží“ aneb slovní ping-pong}

Tato kategorie je ve sledovaném vzorku nejvíce zastoupenou. Nastává ve chvíli, kdy učitel z pohledu rozvíjení kompetence $\mathrm{k}$ řešení problémů slibně vedenou interakci převezme do svých rukou a v podstatě dořeší úlohu za žáky. Typicky učitel zadal úlohu, některý z žáků (oproti potenciálně rozvíjejícím situacím obvykle jen jeden, bez pomoci ostatních) ji začal řešit, ale řešení ani on, často ani jiný žák, nedokončil, někdy ani nedořekl. Tento KDI nabýval ve sledovaných hodinách mnoha podob. První z nich jsou situace, kdy učitel poskytl žákům málo času na přemýšlení, což se projevilo tím, že položil otázku a vzápětí vyvolal prvního, často jediného žáka, který se začal hlásit. To samo o sobě nemusí být nutně hodnoceno neprríznivě - někdy je v pozorovaných hodinách zjevná motivace $\mathrm{k}$ tomuto jednání ve snaze zkrátit délku řešení PO úlohy, jež je obvykle samo o sobě mnohem delší než řešení méně kognitivně náročné úlohy. $\mathrm{V}$ některých situacích to ale vedlo $\mathrm{k}$ tomu, že se značně redukoval počet žáků, kteří se hlásili o slovo, a v důsledku pak i těch, kteří se na řešení podíleli. Některé další důsledky tohoto jevu jsou naznačeny dále.

Málo času ponechaného žákům k promýšlení odpovědi může také ústit v nerovnoměrnou distribuci pozornosti a ve svém důsledku zapř́čcinit to, že bude nakonec velkou část úloh řešit učitel pouze $s$ jed- ním (stále stejným) žákem. $\mathrm{V}$ některých hodinách je pozorovatelné, že si učitel popisovaný problém uvědomil a snažil se poté vtáhnout i ostatní žáky. Vedlo to však v pozorovaných př́padech vždy $\mathrm{k}$ tomu, že ostatní žáci byli zapojeni pouze formálně - jako např. v situaci DS22 (viz níže), v níž řešili mechanismus, resp. činnost svalů při ohýbání končetin. Úlohu vyučující začal řešit se všemi žáky otázkou do tř́dy, vyvolal jednoho žáka. Jeho odpověd' byla uznána jako částečná, možnost opravy ale už nedostal ani on, ani ostatní žáci, nebot úlohu okamžitě začal učitel řešit $\mathrm{v}$ dialogu $\mathrm{s}$ jiným žákem, jehož obvykle vyvolával na náročnější úlohy. Učitel tak dal zdánlivě možnost všem žákům zapojit se, po první neúplné odpovědi však „vsadil na jistotu“. Bylo zřetelné, že kdykoli se daný žák dostal ke slovu, ostatní žáci se stáhli do pasivity, mnohdy se dokonce začali věnovat mimovýukové činnosti. Po vysvětlení flexe a extenze vybraným žákem se učitel znovu pokusil zapojit ostatní žáky, ale tak, že již pouze sborově doplňovali do učitelovy sekvence předem jasná slova: ${ }^{10}$

U: Dobře. Takže díky čemu to je, že jsme pohli rukou? Co ty svaly dělají?

ZZ: Stahují se

[natahují]

U: [Stahují se] a natahují. To znamená, že nepracuje jen jeden sval?

ZZ: Nee.

U: Mohou pracovat dva do páru, nebo dokonce? Zašklebte se na mě a usmějte se na mě. Co myslíte, kolik svalů ted' pracovalo?

\footnotetext{
${ }^{10}$ Transkripty jsou přepsány v souladu s konvencí pro konverzační analýzu (viz Vaníčková, 2014): U - učitel; Z - žák; ZZ - žáci; [v hranatých závorkách] - překrývající se repliky; ((v kulatých závorkách)) - komentáre popisující další jevy; (.) pauza ve výpovědi, počet teček či číslice určuje její délku (u číslice jde o sekundy); = okamžité navázání na předchozí repliku, podtržené slovo - zdůrazněné slovo.
} 
ZZ: Tři, čtyři, jeden, hodně, dva. ((překřikují se každý s jiným tipem))

U: Dva, tři, hodně. Že jo, když se někdo zašklebil hodně, tak asi celý obličej. Děkuju. Posad'se.

(Ukázka ze situace DS22)

V ukázce vidíme, že jakmile žáci začali opakovat spojení stahuji se a natahuji, které několikrát zaznělo již $\mathrm{v}$ předchozím řešení, učitel je nenechal domluvit a v okamžiku, kdy slyšel, že začínají odříkávat naučenou odpověd', byl si zřejmě jistý, že půjde o tu, kterou očekával. Aniž by ji dokončili, potvrdil ji zopakováním jako správnou. Následovala uzavřená otázka o počtu zapojených svalů, jejíž odpověd' byla nasnadě a po předcházející interakci mohla plnit pouze funkci zdůraznění, že jde o více svalů. Vše pak uzavřel otázkou, v níž měli žáci doplnit jedno slovo, přičemž slovem „dokonce“ naznačil, že to bude víc než dva - a stejně vágní byla pak i uznaná odpověd', resp. učitelovo shrnutí. Jde tedy o příklad interakce, v níž učitel diskusi se třídou převedl na rozhovor s jedním žákem a skončil diskusí natolik formální, že šlo spíš o kvazidiskusi.

$\mathrm{V}$ předchozí ukázce byla aktivita ponechána alespoň jednomu žákovi (ostatní vše pouze pasivně přijímali). Další variantou je, že aktivitu učitel po první chybné nebo částečně správné odpovědi stáhl zcela na sebe - $\mathrm{k}$ tomu viz následující ukázka:

Z1: Jak máme správně dýchat? ((čte zadání otázky)) Nosem se nadechnem, pusou vydechnout. Vydechnem.

$\mathrm{U}$ : Je tam nutný to pusou vydechnout?

ZZ: Ne. Z2: To je jedno.

U: To není potřeba. Ale řekl jsi správně=
Z1: =Nemáme vdechovat, když je zima.

U: Proč?

Z3: Abysme se nenachladili=

U: =Abysme se nenachladili. Protože, když se kouknete, tady k tomuto se nám hodí docela obrázek, co vy tam máte. I když ten taky není úplně ideální. Já vám ukážu spíš tadyhle obrázek. Průřez člověka. Takže se nadechujeme nosem a takhle to prostě jde potom směrem dolů do plic. $A$ nebo se můžeme nadechnout pusou, a pak by to šlo stejně tak směrem dolů do plic. Tady máme totiž propojku, jo? Tak to má nějakou výhodu. Kdo má nějaký nápad, proč je lepší se nadechnout tím nosem? Že nám tam nehrozí to nachlazení, Niki.

Z4: Ono to jde dýl do toho, takže on se ten vzduch stačí ohřát jakoby.

U: Výborně. Přesně tak. Nehledě na to, děcka, že ten nos máme ještě uzpưsobený vlastně takovýma droboučkýma chloupkama a tím, že je to tam vlhký, tak se zachytávají všechny možný nečistoty=

\section{Z5: =Můžu?}

U: A právě ty mikroby. A bývá to právě taky v tom seriále, si ted' neuvědomím přesně scénu, ale je to tam taky nějak naznačeno.

(Ukázka ze situace CS19)

Žák přečetl zadanou otázku a rovnou na ni odpověděl, učitel položil otázku, jíž naznačuje možný rozpor, žák se jednoduše opravil, učitel potvrdil správnost a začal konstruovat poznání na tom, co žák řekl správně (aniž ho to předtím nechal dopovědět). Toho se vyvolaný žák „chytil“" a zpřesnil odpověd'. Poté se učitel ptal po zdůvodnění, a toho se mu v jednoduché podobě uplatňující obecnou znalost a bez jakékoli argumentace i dostalo. Zde pak 
nastal kritický didaktický indicent - učitel přestal dále řešit úlohu s žáky, neelaboroval vysvětlení, ale přebral aktivitu na sebe a vše vysvětlil sám, aniž by žáci dostali možnost řešení najít sami nebo aniž by jejich řešení selhalo. Totéž se pak opakovalo dále - učitel se k otázce po částečném vysvětlení znovu vrátil, jako by znovu dával příležitost pro další možné vysvětlení. Žáci se hlásili o slovo, zjevně by rádi úlohu řešili, ale učitel namísto toho, aby stavěl na jejich uvažování a nechal je vysvětlit př́ćinu popsaného jevu, vysvětlil i zbytek sám. Situace tedy mohla být potenciálně nosná, nakonec šlo ale spíše o výklad učitele místy přerušený otázkou.

Poněkud extrémní (ale ve sledované výuce ne zř́dkavou) podobu tohoto kritického incidentu můžeme sledovat $\mathrm{v}$ situacích, $\mathrm{v}$ nichž učitel převzal iniciativu $\mathrm{v}$ řešení úlohy na sebe hned od počátku řešení a žáky řešením prováděl tak, že jej vlastně vytvářl sám. Potenciál problémově orientované úlohy je ale právě $\mathrm{v}$ tom, že žáci hledají nejen výsledek/řešení/odpověd', ale předtím i operaci, pomocí níž bude možné k nim dojít. Pakliže učitel nedal žákům prostor pro hledání těchto operací, zredukoval potenciál na mechanické řešení úloh nižší kognitivní náročnosti. Učitelé pak vlastně řešili úlohu sami a nechali žáky do svého řešení pouze vstupovat, a to obvykle velmi krátkými odpověd'mi na uzavřené otázky, často pouze jednoslovnými. Výsledkem bylo, že namísto poznání žáci pouze pasivně doplňovali údaje, které byly bud' evidentní, a učitelovo přenesení aktivity spojené s odpovědí na žáky bylo tudíž pouze formální, nebo že hádali konkrétní slovo, které měl učitel na mysli. Typickým př́íkladem je sekvence ze situace BS10, jež je zajímavá tím, že problémově orientovanou úlohu ( $\mathrm{Na}$ co použiváme včelí jed?) ${ }^{11}$ položil žák, nikoli učitel (tak je to ovšem u učitele B obvyklé, sám žádnou problémově orientovanou úlohu ve sledovaných hodinách nezadal):

Z: Na co používáme ten včelí jed?

U: Včelí jed? Zase dozvíme se v prezentaci, všechno, co řekneme (..), za chviličku, (..) ale jako lék samozřejmě, jako léčení (.) Co si myslíte, že děláme $z$ toho včelího jedu? Někdo, když ho píchne včela, tak se mu stane co? ((U vyvolá pohledem))

Z: To, že se osype se.

$\mathrm{U}:$ Osype a to?

[Nazýváme to jak]?

Z: [Alergický] záchvat. ((Vykřikne Z, kterého U potom vyvolá))

U: Vojto. ((U napomene Vojtu, pohledem vyvolá někoho jiného))

Z: Alergický záchvat.

U: Alergický záchvat a léky proti tady tomuto alergickému záchvatu na léčení se dělají právě? (3)

ZZ: Z toho jedu $=$.

$\mathrm{U}:=\mathrm{Z}$ toho jedu. Jo, když jdete na očkování proti čemukoli, proti neštovicím nebo proti čemu se chodí ještě? (..) ((ptá se tř́ídy))

ZZ: Tuberkulóza.

U: Černý kašel nebo tuberkulóza, tak oni do vás vždycky stř́iknou co? (.)

Z: Trošku tý nemoci.=

${ }^{11}$ Při posuzování potenciální problémovosti úlohy jsme brali v úvahu dosavadní znalosti žáků, na něž mohlo být usuzováno z předepsaného učiva a dosavadního průběhu hodiny, v níž bylo téma představeno žákům poprvé. Všechny úlohy byly kategorizovány na základě shody dvou kódovatelů (viz Češková \& Knecht, 2016). 
U: =Přesně tak, trošku tý nemoci, aby bylo vaše tělo dokázalo? (1)

ZZ: Přizpůsobit.

U: Přizpůsobit a vyrobit si? (1)

ZZ: Protilátky.

U: Protilátky, tak takhle trošičku na podobným principu právě funguje ten včelí jed, který slouží jako ten lék, ze kterého se dělají léky, jo.

\section{(Ukázka ze situace BS10)}

Učitel žákovi nejprve lapidárně odpověděl jednou z možných odpovědí ( $j a k o$ lék). Samotné nerozvedení situace by samozřejmě bylo legitimním rozhodnutím (zapříčiněným jiným cílem, nedostatkem času apod.), jehož důsledkem by bylo nevyužití didaktického potenciálu. Učitel se nakonec ale rozhodl otázku využít, takže se můžeme podívat na způsob interakce: Učitel se k otázce vrátil, zopakoval ji, avšak namísto poskytnutí času na zamyšlení ihned (podobně jako v jiných situacích u tohoto učitele) začal žákům napovídat. To navíc provedl tak, že výrazně zredukoval problémový prostor a žáky rovnou směřoval $\mathrm{k}$ jednomu konkrétnímu řešení (pro lepší názornost uvedu jeho doplňující otázky v závorce). Hned radil uzavřenými otázkami vyžadujícími využití žákovy zkušenosti (Někdo, když ho pichne včela, tak se mu stane co?) a obecné znalosti (Osype, a to nazýváme jak?). Zde pak odpověd' akceptoval jejím zopakováním a tázal se po upřesnění, resp. po přesnějším pojmenování. Následně pokračoval otázkou, která se kruhem vracela $\mathrm{k}$ již řečenému, takže $\mathrm{k}$ jejímu (žádoucímu) zodpovězení stačilo pouhé zopakování (A léky proti tady tomuto alergickému záchvatu se dělají prá- věe). Následoval pokus o zobecnění otázkou, na niž byla ale odpověd' po dosavadní sekvenci nasnadě (Když jdete na očkování proti čemukoli (...), tak oni do vás vždycky stř́knou co?). Pak učitel uzavřel sekvenci dvěma otázkami (Aby [se] vaše tělo dokázalo? Prizppisobit a vyrobit si?), jejichž odpovědi byly tvořeny spíše ustálenými spojením "tělo se dokázalo přizpůsobit“ a „vytvořit si protilátky“, které stačilo doplnit podle smyslu. Všechny otázky jsou uzavřené a směřují $\mathrm{k}$ odpovědi vyžadující pojmenování učitelem popsaného jevu. Jejich složením pak vznikne možná odpověd' na problémově orientovanou úlohu, nikoli však pomocí konstruování poznání na základě vlastního usuzování žáků. Kritickým incidentem je zde to, že všechny tyto otázky vnáší do řešení učitel.

Celá situace vlastně připomínala slovní ping-pong, $\mathrm{v}$ němž učitel nastavil pálku vždy tak, aby žák mohl „odpálit“ přesně to, co učitel očekával, o nic více, o nic méně. „Taktika“ učiteli zjevně vycházela, nebot žáci skutečně vždy poskytli odpověd' žádoucí a víceméně správnou. Situace tak výsledně vyzněla jako velmi úzce vedená, aktivita i posouvání řešení stálo pevně na straně učitele. Analytická fáze řešení této úlohy trvala sice 42 sekund, ale žáci během ní doplnili kolem 15 slov. Malé zapojení žáků může mít dvě prííčiny, jednak žáci vlivem úzce položené podotázky doplňovali jen velmi krátké, často jednoslovné odpovědi $-\mathrm{z}$ řešení se stalo $\mathrm{v}$ podstatě doplňovací cvičení -, jednak žáky učitel často přerušoval (v záznamu jsou to místa $s=)$, čímž stáčel ihned, jakmile to bylo možné - tedy okamžitě po žákově dopl- 
nění učitelovy věty -, řešení zpět na sebe. Zpětná vazba měla podobu zopakování žákovy (správné) odpovědi a fungovala zároveň jako navázání další vždy uzavřenou otázkou směřující $\mathrm{k}$ jedné konkrétní odpovědi. Šlo tak o skript předepsaný učitelem, který sice může vést k osvojení určitého typu znalostí či k zopakování pojmů, ale potenciál $\mathrm{k}$ tomu, aby se $\mathrm{z}$ „obyčejného ping-pongu" stala problémová úloha, nebyl (stejně jako v ostatních problémově orientovaných situacích $\mathrm{v}$ jeho hodinách) využit. Řešení, ke kterému učitel žáky přivedl, bylo navzdory deklaraci, že se žáci dozvědí o tématu později více, jediným, o němž se v hodině hovoří.

Kritický didaktický incident tedy představuje interakce, $\mathrm{v}$ nichž učitel od počátku do konce žáky velmi přesně vede řešením úlohy, sám ukazuje další podúlohy, značně redukuje prostor pro samostatné uvažování žáků. Žáci pouze hledají v zásadě krátké žádoucí odpovědi, prostor pro jiné odpovědi, než učitel očekává, natož na vlastní invenci žáků, není. Akceptovatelná je vždy jen jedna odpověd', ačkoli jich je možných více (nebo je více způsobů řešení), což přináší značné nevyužití kognitivního potenciálu, který by úloha mohla mít. Nutno konstatovat, že tento typ kritického didaktického incidentu se ve sledovaném vzorku objevil v devíti situacích, takže se jedná o jev nikoli ojedinělý. To, že učitel žákům radí, je obvyklé a žádoucí, vždy ale záleží na míre a způsobu.

Jinou podobu kritického didaktického incidentu můžeme sledovat $\mathrm{v}$ následující ukázce. Celá situace (DS26) se odvíjela ná- sledovně: zadání problémově orientované úlohy předcházela otázka, kolikrát se člověk nadechne za minutu, poté učitel rozdal do dvojic kousek vaty, pomocí níž počítali, kolikrát se nadechnou v klidu žáci ve třídě. Dále žáci odhadovali, kolikrát se nadechnou v zátěži, a následně to i ověrovali - právě to je předmětem ukázky:

U: Dobře. Vyměňte si to. A pozor. A pozor. Ten, který ted' nedrží vatu v ruce, bude muset se trošku pohnout, abysme věděli, co se stane $s$ dechem, když někdo bude dělat, já nevím třeba minutu, dřepy. Co myslíte? Nevykřikuj, nevykřikuj. ((Vyvolá))

Z1: Zrychlí se dýchání.

U: Ǩíkáš, že se zrychlí dýchání. Má pravdu nebo? ((Otázka směřuje na tř́du))

ZZ: Má.

U: Má. Proč? Zkuste mi ríct rovnou proč, Pavle.

Z2: Protože srdce vlastně potřebuje víc výživy, tudíž vlastně se zrychlí tep=

$\mathrm{U}:=$ Jenom srdce?

Z2: Vlastně i svaly.

U: Potřebují víc (..) Verčo, poslouchej to.

Z2: Takže se vlastně musí zrychlit dech, aby se tam rychleji okrvovalo, tím pádem=

U: =Pozor, okrvovalo? Aby se do krve dostával?

Z2: Více vzduch.

$\mathrm{U}: \mathrm{Ky}$ ?

ZZ: Kyslík.

U: Ovšem, jestli je to pravda, to si zkusíme ted', jo?

(Ukázka ze situace DS26)

Zajímavé na situaci je, jak učitel dával cíleně prostor všem žákům. $\mathrm{V}$ otázce týkající se dechové frekvence mohl každý rríct svůj tip. Poté, co počítali skutečnou 
frekvenci, tázal se učitel postupně každé dvojice, kolik „naměřili“, a nakonec se znovu každé dvojice zeptal, kolikrát se cvičící žák nadechl po zátěži. Tato snaha je $\mathrm{v}$ zásadě cenná, problém je, že jde často pouze o formální prostor, který žákům poskytuje. $S$ tipy totiž nebylo nijak pracováno a učitel se $\mathrm{k}$ nim nevracel ani pro srovnání nebo vyvození pravidla. Jde tak spíše o jev formální (učitel dává prostor $\mathrm{k}$ vyjádření všem žákům) než účelný (žáci se aktivně zapojí pouhým vyslovením tipu nebo čísla, tím ale jejich aktivizace končí). Ve výsledku to, že každý mohl říct svůj názor, trvalo více než třetinu času z cca devítiminutové problémově orientované situace. To je zároveň dokonce déle, než trvalo řešení samotné problémově orientované úlohy, a to včetně zahrnutého pokusu a shrnutí. ${ }^{12}$ To ukazuje na další, ve své podstatě nežádoucí jev spojený s výukou orientovanou na kompetence, totiž že príprava na řešení problémově orientované úlohy (zpravidla fáze F1) v praxi někdy trvá déle než řešení samotné úlohy (srov. Češková \& Knecht, 2016).

Na ukázce je pozorovatelný KDI spočívající v tom, že se učitel snažil opravovat každou jednotlivost. To mělo dva důsledky: ačkoli bylo elicitováno zpřesnění žákovy odpovědi, tím, že se ptal okamžitě, ještě během žákovy promluvy, přerušil řešení, čímž došlo $\mathrm{k}$ fragmentarizaci a de facto $\mathrm{k}$ znemožnění komplexnějšího promýšlení úlohy. Učitel tak zaostřil pozornost žáků na dílčí poznatky či detaily, ale cíl úlohy nebyl brán na zřetel. Lze to charakterizovat rčením, že pro stromy nevidí les. $\mathrm{V}$ některých prrípadech pak tento postup vedl k tomu, že se na popisovaných jednotlivostech $\mathrm{v}$ řešení zastavili natolik, že na řešení původní úlohy už ani nedošlo.

Shrneme-li KDI spadající do této kategorie, pak jde o situace, kdy (a) učitel neposkytne dostatečný čas na promyšlení odpovědi; (b) učitel sice dá dostatek času na promyšlení odpovědi, ale nepočká, až žák odpověd' dokončí, „skočí“ mu do řeči a dopoví řešení sám, ačkoli žák ještě neskončil, a to i ve chvíli, kdy se prŕliš neodchýlil od tématu či možného způsobu řešení, nebo když (c) učitel udělá totéž po první správné variantě a namísto elaborování dalšího možného řešení je žákům sám vyloží či když (d) zúží problémový prostor natolik, že žáky o vlastní zkoumání de facto připraví. Do této kategorie spadají i situace, kdy (e) učitel v okamžiku první chyby $\mathrm{v}$ řešení žáka přeruší a namísto toho, aby jej na chybu upozornil, dal př́ležitost ostatním jej opravit nebo mu jinak poradil, aktivitu převezme sám a řešení žákům transmisivně předloží. Pro všechny tyto varianty je společné to, že je žák přerušen v průběhu procesu

\footnotetext{
${ }^{12}$ Situace sestávala z několika fází - úvodní tipování a počítání dechové frekvence v klidu jsme zařadili do iniciační fáze (F1), analyzování (F2) začíná zadáním problémově orientované úlohy a končí jejím řešením (viz transkript), následuje ověřování pokusem, jež jsme zařadili do vyhledávání/zjištování informací (F3), pokračovala syntéza (F4) v podobě shrnování výsledků a jejich prrípadného posouzení vůči ostatním žákům a situace byla zakončena kratičkým shrnutím (F5) toho, co se mělo při pohybu s dechem stát.
} 
řešení. To může $e^{13}$ mít několik příčin: jednak obligátní úspora času, jednak snaha zavést pozornost skrze odpověd' $\mathrm{k}$ dalšímu jevu, o němž bude v budoucnu řeč, a jednak prostá snaha učitele mít výuku „pod kontrolou“. Může to být ale také způsobeno vlastní nejistotou, at už v oborových znalostech (když je dán prostor žákům, mohou „přijít" na něco, co učitel nezná), nebo nejistotou pedagogickou, tedy tím, jak vést konstruktivní dialog. Výsledkem pak je, že žáci sice mají možnost aktivního zapojení, ale pouze limitovaného prostorem mezi učitelovým zadáním a vysvětlením, často aktivně pasivním, tedy že sice jsou aktivně zapojeni, ke kognitivní aktivitě či rozvíjení kompetencí ale dochází minimálně. Tak se dostáváme $\mathrm{k}$ další skupině incidentů.

\subsection{Když poznání „uteče“ aneb odvedené poznávání}

Některé situace jsou charakteristické tím, že ačkoli se během nich realizovalo řešení problémově orientované úlohy, $\mathrm{k}$ vyřešení nedošlo. Nejčastěji to bylo způsobeno tím, že učitel radil žákům pomocí podotázky, která jim měla přiblížit podobný jev v jiném kontextu, namísto toho je ale odvedla od tématu. V interakci učitele se tř́dou diskutovali nad odpovědí na podotázku, tu zodpověděli, ale $\mathrm{k}$ původní otázce se již nevrátili. Totéž následovalo ve chvíli, kdy chtěl učitel poradit tak, že reformuloval tutéž otázku. Př̀i snaze o přeformulování otázky posunul její význam natolik, že již neodpovídala původnímu cíli úlohy. Extrémní podobou pak je, že k řešení problémově orientované úlohy nedošlo vůbec. Ve sledovaném vzorku byl identifikován jediný výskyt tohoto kritického didaktického incidentu, a to u problémově orientované otázky, kterou položil žák, vyučující neznal odpověd' a ani přes značný zájem žáků a tematickou relevantnost ji s žáky nezkusil najít. I to je však legitimní postup, nebot́ učitel $\mathrm{v}$ každou chvíli výuky vyhodnocuje dosavadní průběh a zvažuje, jakým směrem ji povede dále. Mohl tedy vyhodnotit, že jde kupř. o irelevantní odbočení od tématu či že by je řešení mohlo př́iliš časově zatížit.

Za situace $s$ velkým potenciálem ke zlepšení lze považovat ty, kde docházelo pouze $\mathrm{k}$ plytkému poznávání. Ukažme si to na situaci $S 6$ z hodiny A2, v níž se řeší odpadky v nasimulovaném rybníce:

U: To byl nějakej kluk určitě a priš̌el semka vysypat nějakej odpad. Já se do toho rybníka podívám, co to je?

T: Obal.

U: Děcka a ted' se vás zeptám. Podívejte se, najednou nám to plave po rybníku, v rybníce to je, co myslíte, $z$ čeho to je, $z$ čeho to je? Přihlásíme se. Katko.

Z: Z papíru.

U:Z papíru. A myslíte si, za jak dlouho se rozloží papír (.) ve vodě.=

Z: =Za pět dní.=

Z: $=$ Za chvilku.

U: Za pět dní, to je brzo.

$\overline{{ }^{13}}$ Zde se projevuje limit výzkumu v tom, že nemáme výpovědi učitelů zacílené na tuto stránku hodiny, můžeme se tedy pouze na základě viděného domnívat, jakou př́činu mohou dané jevy mít. 


\section{Z: Za pět minut.=}

$\mathrm{U}:=$ To je ještě drív.

$Z: Z a$ deset dnů.

Z: Za týden.

Z: Za setinu.

Z: Nikdy.=

U: =Za několik týdnů určitě. ((U si stoupne, ukončí tipování)) Takže s papírem dokáže se rybník, voda vyrovnat?=

$$
\begin{aligned}
& Z:=[\text { Ano] } \\
& \text { U: }=[\text { Jakžtakž jo. }] \\
& Z:=[\mathrm{Ne}] \\
& \text { U: Co se nám tady objevilo? }
\end{aligned}
$$

ZZ: Sklo.

U: Ježišmarja, sklo. Jak dlouho tam bude v tom rybníce, děcka, [co myslíte].

$Z:$ [Hodně dlouho.]

Z: Aspoň navždy.=

$Z:=$ Napořád.

$\mathrm{Z}:=\mathrm{Ne}-\mathrm{e}$

Z: Napořád.

U: Myslíte si, že se sklo rozloží=

$\mathrm{Z}:=\mathrm{Ne}$.

U: nějak samo?

Z: Ano.

$\mathrm{Z}: \mathrm{Ne}$

U: Tomáš myslí ano, kdo si myslí, že ne, zvedne ruku. (2) ((ZZ zvedají ruce))

Z: Já.

U: Mhm. Kolik rukou nahoře? (1) Sklo tam bude, sklo tam zůstane.

(Ukázka ze situace AS2)

Učitel probíral se žáky materiály, z nichž jsou vyrobené odpadky vysypané $\mathrm{v}$ rybníku. Začali papírovým obalem, učitel se ptal, z čeho je vyroben a jak dlouho bude trvat, než se ve vodě rozloží. Následovala série žákovských tipů, které uči- tel korigoval pouze slovy „za pět dní, to je brzo" a "to je ještě dřív". Skončil však u obecné znalosti, že papír se ve vodě rozloží, a odpověd” „odsouhlasil“" se zcela jiným časovým údajem, než tipovali žáci, aniž by to bylo nějak reflektováno. $S$ tipy nebylo dále nijak pracováno, řešení žáci nezdůvodňovali, neřešili kontext, dokonce když učitel položil otázku, k níž celá situace směřovala (zda se rybník s papírem dokáže vyrovnat), otázka zůstala v podstatě řečnickou, resp. učitel nečekal na odpověd’ a odpověděl sám. Totéž se opakovalo u skla, kde sekvence skončila u hlasování, s nímž opět nebylo nijak pracováno, a pouhým konstatováním, že „sklo tam zůstane“. Následovala táž varianta s plasty (již mimo ukázku), s nimiž mají žáci zřejmě díky společenské relevantnosti dané problematiky větší zkušenost, takže se rozhovořili i o vlastních zkušenostech, za ně však řešení opět nešlo. Celá situace skončila bez shrnutí, závěr si musel každý vyvodit sám. Tím, že nedocházelo $\mathrm{k}$ hlubšímu promýšlení souvislostí ani $\mathrm{k}$ práci s tipy žáků, zůstal proces řešení na nejnižší kognitivní úrovni, celá situace nesla minimální didaktický potenciál a její účel tak mohl být pouze $\mathrm{v}$ motivaci $\mathrm{k}$ následující aktivitě týkající se vhodnosti jednání lumpa, který odpadky do rybníku vysypal.

Popsaná situace nám ukazuje tedy hned dvě podoby popisovaného KDI když se učitel spokojí s plytkým poznáním a když se spokojí s poznáním bez kontextu, zdůvodnění, vysvětlení, a v důsledku tedy bez porozumění. Vyučování bez porozumění je jedním z nejčastějších KDI a mủže $\mathrm{k}$ němu dojít $\mathrm{i}$ tehdy, když učitel 
poznatky žáků neshrne a neusadí do kontextu již stávajících znalostních struktur. Žáci si tak můžou odnést poznatek, že něco nějak je, ale nemusejí rozumět tomu proč.

Ve sledovaných hodinách se samozřejmě setkáváme také $s$ běžnými pedagogickými chybami - i učitel je člověk chybující. Např́klad učitel označí jako chybné i správné řešení, nebo naopak označí jako správné i chybné řešení či uzná pouze jedno řešení a ostatní považuje za chybu; nebo učitel poskytne žákům nápovědu, která nepomůže, ale zmate, nebo dokonce odvede žáky mimo téma. Tento KDI se ale objevoval poměrně zř́dka a obvykle měl podobu dobře míněné rady, kdy učitel předpokládal znalost z jiného kontextu, již však žáci neměli, takže rada se u žáků nesetkala $s$ porozuměním, resp. nedošlo $\mathrm{k}$ vzájemnému dorozumění.

Ve sledovaných situacích se nezř́idka objevují zjednodušení vedoucí na hranu oborové správnosti, někdy dokonce i za ni - to jsme ostatně mohli částečně pozorovat $\mathrm{v}$ ukázce týkající se práce svalů (DS22), v ukázce zaměřené na dechovou frekvenci (DS26) i v ukázce zabývající se hledáním odpovědi na to, $\mathrm{k}$ čemu se využivá včelí jed (BS10). Oborová správnost jde samožrejmě ruku v ruce s pedagogickými dovednostmi, není však předmětem této studie upozorňovat na oborové chyby, kterých si učitelé patrně nebyli vědomi a které učinili v situacích, jež zjevně řešili $s$ nejlepším vědomím. A ačkoli je vnímám, v ohledu na procesní stránku, na niž je studie zaměřena, je záměrně pomíjím.

\section{DisKuSE}

$\mathrm{V}$ prezentované studii jsem si kladla za cíl analyzovat, proč situace, v nichž byla problémově orientovaná úloha nastolena, nenaplní svůj potenciál - rozvíjet $\mathrm{u}$ žáků kompetenci $\mathrm{k}$ řešení problémů. Sledovala jsem běžnou výuku, učitelé tedy neměli zadáno, aby se specificky zaměrili na rozvíjení kompetence $\mathrm{k}$ řešení problémů. Rozvíjení klíčových kompetencí má však z podstaty prostupovat celou výukou (viz RVP ZV, 2016), takže analýza situací, které pŕíležitost nabídly, ale nebyly využity, je v tomto kontextu legitimní. Je však stále nutné mít na paměti to, že učitel v danou chvíli mohl sledovat jiný cíl.

$\mathrm{V}$ úvodu diskuse je třeba také uvést, že kritický incident nelze interpretovat jako nedostatek profesní kompetence. Jak upozorňuje Amade-Escotová (2005, s. 142), kritický incident lze identifikovat jak u začínajících učitelů, tak u učitelů-expertů. Nejde tedy o kritiku učitelů a jejich řešení nastalé pedagogické situace, nebot ve výuce intervenuje tolik proměnných, že důvodů, proč ji vedli určitým způsobem, může být celá řada. Mojí snahou bylo spíše upozornit na opakující se jevy, jež ve výuce oslabují rozvíjení kompetence $\mathrm{k}$ řešení problémů, ačkoli $\mathrm{k}$ němu zadaná úloha směřovala. Ostatně už Flanagan (1954) považuje za smysl analýzy kritických incidentů vytvoření soupisu typických chyb, tedy toho, na co si dát pozor - ovšem s poznámkou, že to nelze posuzovat kriteriálně a formálně a že vždy záleží na způsobu realizace. 


\subsection{Celkový pohled na sledované situace}

Kvalitativní analýza kritických didaktických incidentů proběhla na vzorku 19 výukových situací, které stavěly na problémově orientovaných úlohách, avšak zároveň nebyly hodnoceny jako rozvíjející. Už jen to, že se v ní úlohy nesoucí potenciál rozvíjet kompetenci $\mathrm{k}$ řešení problémů objevují, je dobrou zprávou - vždyt́ na druhém stupni ani to není samozřejmé. Např́iklad Knecht (2014) zjistil, že (v zeměpise) na druhém stupni se problémově orientovaná výuka téměř nevyskytuje. Mají-li být rozvíjeny klíčové kompetence, je třeba se ve výuce zaměřit na transfer neboli přenášení poznatků mezi situacemi (včetně přenášení mezi teorií a praxí) a generalizaci (podrobněji viz Janík et al., 2013, s. 199). To vyžaduje orientovat se ve výuce na úlohy vyšší kognitivní náročnosti, avšak nikoli pouze $\mathrm{v}$ rovině zadání.

V̌̌echny situace sledované v této studii (tedy situace, které nejsou považovány za rozvíjející) byly organizovány jako rozhovor učitele se tř́idou. Tato forma převažovala i u vzorku rozvíjejících situací (viz Češková, 2020a) a je také formou pro českou výuku typickou (viz studie TIMSS, Roth et al., 2006; Najvar et al., 2011). Je tedy evidentní, že nejde pouze o formu výuky, ale i o míru, a především o způsob zapojení učitele. Jak upozorňují Molinariová a Mameliová (2013), je právě vtahování žáků do diskuse, v níž je učivo vysvětlováno, pro první stupeň typickým způsobem rozvíjení argumentačních (i jiných) dovedností u žáků.
Nassaji a Wells (2000) pak v souvislosti $s$ výukou prírodních věd na prvním stupni ukazují, jak pozitivní efekt má společné hledání a vyjednávání odpovědi i na zapojení žáků.

Už sama distribuce potenciálně rozvíjejících problémově orientovaných situací ve sledovaných hodinách a těch, které vykazují potřebu alterace (viz tab. 1), ukazuje, že záleží na tom, zda a jak učitel má osvojený tento konstruktivisticky vedený typ výuky (srov. Selley, 2013; Tobin, 1993). Shrneme-li poznatky, které o vzorku máme, vidíme poměrně výrazné rozdíly mezi jednotlivými vyučujícími. V hodinách vyučujících $\mathrm{A}$ a $\mathrm{C}$ byl pozorovatelný poměrně vysoký počet problémově orientovaných výukových situací, $\mathrm{z}$ nichž aspoň polovinu můžeme považovat za rozvíjející. Lze se tedy domnívat, že situace zařazené do prezentované analýzy nepřicházejí o potenciál rozvíjet kompetenci $\mathrm{k}$ řešení problémů proto, že by tito vyučující problémově orientovanou výuku „neuměli“ ve svých hodinách aplikovat. Naopak je tomu u učitelů B, D a $\mathrm{E}$; ačkoli do své výuky taktéž zařadili problémově orientovaných úlohy, naléhavost alterací, tedy „závažnost odchylky posuzované situace od předpokládaného ideálního stavu" (Slavík et al., 2017, s. 338), v jejich průběhu je vysoká, nebot vždy pouze jednu z pozorovaných situací bylo možné označit za rozvíjející, u učitele B dokonce žádnou (problémově orientované úlohy do hodin učitele $B$ navíc vnášeli žáci, nikoli učitel). Zbylé situace, které nejsou hodnoceny jako rozvíjející, zabraly více než $80 \%$ celkového času 
stráveného problémově orientovanou výukou. Jinými slovy, ačkoliv se problémově orientované úlohy ve výuce těchto učitelů objevují a jejich řešení je věnováno nemálo času, většinu této doby nelze považovat z hlediska potenciálu rozvíjení kompetence $\mathrm{k}$ řešení problémů za efektivní. To podtrhuje domněnku o souvislosti $s$ vyučovacím stylem učitele, který má dominantní vliv na míru zapojení žáků (srov. systematická přehledová studie Howe \& Abedin, 2013).

Při posuzování jednotlivých situací bylo nutné vždy uvažovat $\mathrm{v}$ kontextu celých vyučovacích hodin. Je zřejmé, že některé problémově orientované situace nebyly využity kvůli času, organizačním důvodům či např. jinému cíli, který vyučující sledoval, nebot problémově orientovaná výuka je jen jednou z cest, jak zprostřredkovávat žákům nové znalosti. Ovšem i s přihlédnutím $k$ výše uvedenému analýza ukázala, že ve výuce některých učitelů nebyl potenciál problémově orientované výuky využit nikdy nebo téměř nikdy a že tedy možná vůbec nevědí, jak takovou výuku vést, nebo se o ni snaží, ale bez větší efektivity. To můžeme pozorovat např. v hodinách učitele $\mathrm{D}$, který problémově orientované úlohy předkládá žákům často, snaží se je zapojit $v$ co největší možné míře, ale výsledkem je spíše kvazidiskuse, nebo u učitele $B$, kde tato snaha vyústila vždy ve slovní „ping-pong“. Ve výsledcích lze vysledovat několik „typických“, často se vyskytujících kritických incidentů, které brání využití potenciálu problémově orientovaných úloh.

\subsection{Kritické didaktické incidenty $\mathrm{v}$ kontextu problémově orientované výuky}

V souvislosti s analýzou kritických didaktických incidentů v problémově orientované výuce se nelze ubránit hledání analogií s didaktickými formalismy, jež Janík a kol. (2013; dále rozprac. in Slavík et al., 2017, s. 372 an.) obecně vymezili jako nesoulad (dezintegraci) mezi třemi klíčovými determinantami kvality výuky: 1. učebním obsahem, 2. žákovskou zkušeností a motivací, 3. společným jednáním žáků a učitele, které má směřovat $\mathrm{k}$ cílům výuky. Některé př́klady uvedu dále.

Dominantní skupinou incidentů bylo př́lišné vztahování aktivity na učitele, které se projevovalo tím, že učitel natolik žáky provázel řešením úlohy, že ji de facto řešil sám. Popisované KDI nápadně připomínají protetické poznáni (Hejný, 1989, rozprac. 2004), které nastává v situaci, kdy učitel podsouvá žákům svůj postup řešení, jejž ale žáci príijmou jako fakt, aniž by porozuměli proč. To se pak obvykle projeví ve chvíli, kdy mají naučené aplikovat $\mathrm{v}$ jiném kontextu, zdůvodnit řešení apod. O podobných závěrech hovoří např. Woods-McConneyová, Wosnitza a Sturrocková (2016), když popisují, že byly interakce vysoké úrovně v badatelsky orientované výuce, na niž se zaměrovali, zrrídkavé a krátké, často hned v počátku řešení utlumené vlivem toho, že iniciativu převzal učitel.

Už to, že byl ve výuce dominantní učitel, jde proti základní zásadě problémově orientované výuky - přenesení aktivity 
na žáka (viz Barrows, 1996). I zde je třeba brát do úvahy mnohokrát vzpomínaný jiný možný cíl, který učitel úlohou sledoval. Aktivita žáků však přes zadání, které nabízelo žákovské elaborování řešení, mnohdy spočivala pouze $\mathrm{v}$ tom, že doplňovali slova podle smyslu věty nebo naučených frází namísto vlastní iniciativy, návrhů na způsob řešení, využívání dosavadních znalostí a souvislostí v novém kontextu apod. Jsou tak sice zdánlivě aktivní, ale jejich aktivita směruje spíš než $\mathrm{k}$ porozumění obsahu k hledání slov, která se hodí $\mathrm{k}$ doplnění učitelových vět. Důsledkem může být, že je jim celkové poznání utajeno, tedy že jde o utajené poznáváni (Slavík et al., 2017, s. 386-387). ${ }^{14} \mathrm{~V}$ některých situacích žáci prostě hádali, co má učitel na mysli. $\mathrm{Na}$ tyto nebo podobné charakteristiky upozorňuje rovněž Šalamounová a kol. (2017), kteří je uvádějí jako př́klad bezúčelných pasáží (ve smyslu dialogického vyučování), jejichž účelem je pouze se trefit do žádoucího slova a které nemají pro učení př́lišnou hodnotu, pouze způsobují zbytečnou časovou ztrátu.

Další skupina incidentů může být charakterizována jako nedostatečné elaborování žákovských řešení. Může to mít dvě př́činy: Bud' učitel nevyžadoval víc než jednu odpověd', nebo se spokojil s odpovědí plytkou či bez argumentu (o užitečnosti a smysluplnosti argumentování v primární výuce př́rodních věd viz např. Naylor, Keogh \& Downing, 2007, či Si- mon \& Richardson, 2009), a nevyužil tak dostatečně možnosti, které mu úloha dávala. Jako druhou prŕćčinu lze předpokládat, že žáci mohli vnímat úlohu jako „jednu z mnoha“, nikoli jako problémově orientovanou. Woods-McConneyová, Wosnitza a Sturrocková (2016) totiž v této souvislosti dokládají, že potenciál aktivizujících metod zůstává nevyužit i vlivem toho, že si žáci nebyli vědomi charakteru úlohy (v jejich př́padě toho, že je úloha badatelsky orientována) a nehledali jinou než nejjednodušší odpověd'. Slavík a kol. (2017, s. 373-375) v souvislosti se situací, v níž jsou dány podněty, které by mohly vést žáka $\mathrm{k}$ poznání, ale nejsou dostatečně funkční, aby mohlo dojít $\mathrm{k}$ hlubšímu porozumění obsahu a dorozumění se o něm, a tedy ani ke kognitivní aktivizaci žáků, hovoř́ jako o odcizeném poznávání. Za jistou formu odcizeného poznávání pak můžeme považovat výše popisovaný KDI, $\mathrm{v}$ němž se učitel snaží žákům poradit, ale otázkou, kterou jim napovídá, žáky od původní otázky odvede. Navrhuji pro tento př́pad v souladu s názvem kapitoly, která jev popisuje (kap. 4.2), název odvedené poznávání.

V̌̌dy je nutné, aby bylo poznání získané skrze řešení problémově orientované úlohy na konci shrnuto a usazeno do stávajících struktur, aby došlo $\mathrm{k}$ hlubšímu porozumění nejen toho, co se žáci naučili, ale také toho, co předtím věděli a jak úlohu řršili (srov. Myhill, 2006). Reflexe

\footnotetext{
${ }^{14} \mathrm{~V}$ popisovaných situacích, $\mathrm{v}$ nichž došlo $\mathrm{k}$ označení chybného řešení za správné a naopak, a vnesl-li do výuky chybné odborné informace učitel, vedla výuka v důsledku k osvojení chybných konceptů. Tento prípad označuje Jáč (2017; a rozprac. Slavík et al., 2017) jako zavádějici poznávání.
} 
způsobu řešení, jež je mnohými autory považováno za klíčovou část řešení (viz např. Savery, 2019), chyběla ve sledovaných situacích úplně (o tom více $\mathrm{v}$ předchozích studiích). Nedostatečné provázání či usazení nově nabytých znalostí do stávajících struktur se ale ukázalo jako další z kritických momentů $\mathrm{v}$ problémově orientované výuce - i když došlo $\mathrm{k}$ vyřrešení problémově orientované úlohy a na řešení se podíleli žáci aktivně, $\mathrm{v}$ téměř polovině sledovaných situací zůstalo řešení bez shrnutí či bez usazení do stávajících kognitivních struktur. Takový incident lze považovat za př́iklad nezavršeného poznáváni a koresponduje s nálezy Myhillové a Dunkina (2005), kteří ukazují, jak často k popisovanému jevu ve výuce dochází.

Zároveň právě toto je významným prvkem, který překonává tolik kritizované odtržení oborových znalostí a obsahovou vyprázdněnost ve výuce zaměřené na rozvíjení klíčových kompetencí (viz např. Willbergh, 2015; Štech, 2013; Kaščák \& Pupala, 2009). Jak tvrdí např. Hung (2019, s. 249), „problémy slouží jako prostředky pro oborové znalosti, jimž se žáci mají naučit“. Problémově orientovaná výuka tedy má být naopak v obsahu výrazně zakotvena.

\subsection{Limity výzkumu a závěr}

Jak již bylo naznačeno, tento výzkumný př́stup má řadu limitů. Limitem studie je zajisté využití pouze jednoho zdroje informací - videozáznamů, resp. transkriptů, a tedy pozitivistický náhled. Kdyby byla př́ležitost vést nad identifiko- vanými kritickými incidenty s vyučujícími rozhovor, jistě by to přineslo bohatší a přesnější data - můžeme se ovšem domnívat, že by se týkala zejména oblasti organizace (způsobené napřr. zohledněním únavy žáků), a nikoli prrímého působení učitele ve smyslu způsobu poskytování rad během řešení problémově orientované úlohy. Dalším přiznaným limitem a zároveň největší výhodou je, že nejsou zkoumány hodiny, $\mathrm{v}$ nichž měli učitelé zadáno orientovat se na rozvíjení dané kompetence, ba naopak, v tomto vzorku mělo jít o hodiny co nejběžnější, jejichž primární cíl mohl být (a také zřejmě byl) v jiných oblastech, než je rozvíjení kompetence $\mathrm{k}$ řešení problémů. Vzhledem $\mathrm{k}$ tomu, že rozvíjení klíčových kompetencí by se mělo prolínat celým kurikulem a pomocí tohoto vzorku jsme získali náhled na běžnou, $v$ dobrém slova smyslu průměrnou výuku, jde také o př́ležitost poukázat na to, jak moc se problémová výuka v hodinách (našeho vzorku) ne/objevuje (viz předchozí studie), a pokud ano, tak v jakých podobách. Limitem je jistě i to, že stavím na teorii vybudované na vzorku pěti vyučujících, a také kvůli omezenému počtu natočených hodin a posuzovaných situací rozhodně nelze př́liš zobecňovat. Studie slouží pouze jako orientační vhled do problematiky. $\mathrm{Na}$ druhou stranu prvotní analýza problémově orientovaných situací v 10 hodinách vlastivědného učiva u jiného vzorku vyučujících (Češková, 2018) ukázala na výsledky velmi podobné těm, jaké byly na vzorku prrírodovědném. Můžeme se tedy domnívat, že šlo o poměrně reprezentativní výběr. Bude 
zajímavé popisovanou teorii sledovat, dále ověrovat a pozorovat, $z d a$ a $v$ čem se výuka zachycená $\mathrm{v}$ těchto vzorcích bude lišit a zda kontextová data, která u druhého vzorku byla sesbírána, přinesou i bohatší výsledky. Jak bylo řečeno, studie byla zaměřena na interakci ve výuce. Bylo by užitečné a potřebné ověrit také efektivitu popisované výuky, a potažmo i neefektivitu popisovaných incidentů, na samotné učení žáků.

Závěrem je třeba v souladu s Janíkem a kol. (2013, s. 199) konstatovat, že orientace na rozvíjení klíčových kompetencí je náročná jak pro žáka, především kvůli požadavkům na kognitivní procesy probíhající při takové výuce, tak pro učitele, zejména $\mathrm{v}$ jeho didaktické práci a reflexi. Je tomu tak zejména kvůli nutnosti promyšlenější strukturace, resp. propojování učebních obsahů, a kvůli nárokům na průběh didaktické transformace, kte- rá vezme tyto vyšší cílové úrovně do hry. $\mathrm{V}$ této studii jsem se snažila pomocí mikroanalytického prýstupu ukázat právě na konkrétní podoby průběhu problémově orientované výuky s cílem popsat konkrétní jevy, kvůli nimž potenciál, který má, není využit. Poukázala jsem v této souvislosti na dva jevy, které by bylo užitečné zkoumat dále spolu $s$ učiteli: někteří učitelé si možná myslí, že kompetenci rozvíjejí, ale interakci vedou způsobem, který k tomu nepřispívá, a jiní učitelé mnohdy potenciál úlohy zřejmě ani nevidí nebo jej nevnímají jako důležitý, takže jej ve své výuce (téměř) nikdy nevyužijí. Pojmenování některých jevů, které oslabují rozvíjení klíčových kompetencí ve výuce, může pomoci konkrétními ukázkami, čeho se v praxi vyvarovat. Ve svém důsledku tedy může studie přispět $\mathrm{k}$ poznání, jak by výuka, jež v sobě ohled na kompetence nese, vypadat měla, resp. mohla.

\section{Literatura}

Amade-Escot, C. (2005). Using the critical didactic incidents method to analyze the content taught. Journal of Teaching in Physical Education, 24(2), 127-148.

Analyza zahraničnich systému hodnoceni kličcových kompetenci a systému hodnoceni netestovatelných dovednosti se souborem doporučeni pro školni hodnoceni kličových kompetencí RVP ZV a externi hodnoceni školni podpory rozvijení kličcových kompetenci RVP ZV (2018). Praha: Česká školní inspekce.

Angelides, P. (2001). The development of an efficient technique for collecting and analyzing qualitative data: The analysis of critical incidents. International Journal of Qualitative Studies in Education, 14(3), 429-442.

Barrows, H. S. (1996). Problem-based learning in medicine and beyond: A brief overview. New Directions for Teaching and Learning, 68, 3-12.

Barrows, H. S., \& Tamblyn, R. M. (1980). Problem-based learning: An approach to medical education. New York: Springer.

Bruster, B. G., \& Peterson, B. R. (2013). Using critical incidents in teaching to promote reflective practice. Reflective Practice, 14(2), 170-182. 
Butterfield, L. D., Borgen, W. A., Amundson, N. E., \& Maglio, A. S. T. (2005). Fifty years of the critical incident technique: 1954-2004 and beyond. Qualitative research, 5(4), 475-497.

Cohen, L., Manion, L., \& Morrison, K. (2011). Research methods in education. London: Routledge.

Češková, T. (2016). Výukové situace rozvíjející kompetenci k řešení problémů: Teoretický model jako východisko pro jejich analýzu. Pedagogika, 66(5), 530-548.

Češková, T. (2018). The differences between problem-oriented learning situations in Czech primary geography and Czech primary science. In 2018 IGU Regional Conference - CAG Annual Meeting - NCGE Annual Conference, Quebec, Kanada.

Češková, T. (2020a). Interakce při řešení problémově orientovaných úloh ve výuce př́rodovědy. Orbis scholae, 14(1), v tisku.

Češková, T. (2020b). Přiležitosti k rozvijeni kompetence k řešeni problémů ve výuce na 1 . stupni (na príkladu prírodovédného učiva): Komentář k souboru prací. (Dizertační práce). Masarykova univerzita.

Češková, T., \& Knecht, P. (2016). Analýza problémově orientovaných výukových situací ve výuce přírodovědy. Orbis scholae, 10(2), 93-115.

Davies, H., \& Kinloch, H. (2000). Critical incident analysis. In V. E. Cree \& C. Macaulay (Eds.), Transfer of learning in professional and vocational education (s. 137-147). London: Routledge.

Delisle, R. (1997). How to use problem-based learning in the classroom. Alexandria, VA: Association for Supervision \& Curriculum Development.

Etherington, M. B. (2011). Investigative primary science: A problem-based learning approach. Australian Journal of Teacher Education, 36(9), 36-57.

Fidrmuc, J. (2018). Revize RVP všeobecně vzdělávacích predmětů. Př́íspěvek prezentovaný na konferenci Konstruktivistické přístupy ve vzdělávání v perspektivě (nejen) oborových didaktik, Brno.

Flanagan, J. C. (1954). The critical incident technique. Psychological Bulletin, 51(4), nestr.

Francis, D. (1997). Critical incident analysis: A strategy for developing reflective practice. Teachers and teaching, 3(2), 169-188.

Goodell, J. E. (2006). Using critical incident reflections: A self-study as a mathematics teacher educator. Journal of Mathematics Teacher Education, 9(3), 221-248.

Griffin, M. L. (2003). Using critical incidents to promote and assess reflective thinking in preservice teachers. Reflective Practice, 4(2), 207-220.

Hanuscin, D. L. (2013). Critical incidents in the development of pedagogical content knowledge for teaching the nature of science: A prospective elementary teacher's journey. Journal of Science Teacher Education, 24(6), 933-956.

Harrison, J. K., \& Lee, R. (2011). Exploring the use of critical incident analysis and the professional learning conversation in an initial teacher education programme. Journal of Education for Teaching, 37(2), 199-217.

Hejný, M. (1989). Teoria vyučovania matematiky 2. Bratislava: SPN.

Hejný, M. (2004). Mechanismus poznávacího procesu. In M. Hejný, J. Novotná \& N. Stehlíková (Eds.), Dvacet pèt kapitol z didaktiky matematiky (s. 23-42). Praha: Pedagogická fakulta UK. 
Hennings, J., Wallhead, T., \& Byra, M. (2010). A didactic analysis of student content learning during the reciprocal style of teaching. Journal of Teaching in Physical Education, 29(3), 227-244.

Hole, S., \& McEntee, G. H. (2003). Reflection is at the heart of practice. In G. H. McEntee (Ed.), At the heart of teaching: A guide to reflective practice (s. 50-60). New York: Teachers College Press.

Howe, C., \& Abedin, M. (2013). Classroom dialogue: A systematic review across four decades of research. Cambridge Journal of Education, 43(3), 325-356.

Hughes, H. (2007). Critical incident technique. In S. Lipu, K. Williamson \& A. Lloyd (Eds.), Exploring methods in information literacy research (s. 49-66). Wagga Wagga: Centre for Information Studies.

Hung, W. (2019). Problem design in PBL. In M. Moallem, W. Hung \& N. Dabbagh (Eds.), The Wiley Handbook of problem-based learning (s. 249-272). Boston: Wiley.

Jáč, M. (2017). Proteosyntéza eukaryot: hledání cesty od znalosti pojmů k hlubšímu porozumění buněčným procesům ve výuce biologie. In J. Slavík, J. Stará, K. Uličná \& P. Najvar (Eds.), Didaktické kazuistiky v oborech školního vzděláváni (s. 283-308). Brno: Masarykova univerzita.

Janík, T., Slavík, J., Mužík, V., Trna, J., Janko, T., Lokajíčková, V., ... Šebestová, S. (2013). Kvalita (ve) vzdèláváni: obsahově zaměrený prístup ke zkoumáni a zlepšováni výuky. Brno: Masarykova univerzita.

Jonassen, D. H. (2011). Learning to solve problems: A handbook for designing problem-solving learning environments. New York: Routledge.

Kaščák, O., \& Pupala, B. (2009). Výchova a vzdelávanie v základných diskurzoch. Prešov: Rokus.

Klieme, E., Schümer, G., \& Knoll, S. (2001). Mathematikunterricht in der Sekundarstufe I: Aufgabenkultur und Unterrichtsgestaltung. In E. Klieme \& J. Baumert (Eds.), TIMSS-Impulse für Schule und Unterricht (s. 43-57). Bonn: Bundesministerium für Bildung und Forschung.

Knecht, P. (2014). Príležitosti k rozvijeni kompetence k řešeni problémů v učebnicich a ve výuce zeměpisu. Brno: Masarykova univerzita.

Lister, P. G., \& Crisp, B. R. (2007). Critical incident analyses: A practice learning tool for students and practitioners. Practice, 19(1), 47-60.

Maxwell, J. A. (2010). Validity: How might you be wrong. In W. Luttrell (Ed.), Qualitative educational research: Readings in reflexive methodology and transformative practice (s. 279-287). New York: Routledge.

Moallem, M., Hung, W., \& Dabbagh, N. (Eds.). (2019). The Wiley Handbook of problem-based learning. Boston: Wiley.

Mohammed, R. (2016). Critical incident analysis: Reflections of a teacher educator. Research in Teacher Education, 6(1), 25-29.

Molinari, L., \& Mameli, C. (2013). Process quality of classroom discourse: Pupil participation and learning opportunities. International Journal of Educational Research, 62, 249-258.

Myhill, D. (2006). Talk, talk, talk: Teaching and learning in whole class discourse. Research Papers in Education, 21(1), 19-41. 
Myhill, D., \& Dunkin, F. (2005). Questioning learning. Language \& Education, 19(5), 415-427. Najvar, P., Najvarová, V., Janík, T., \& Šebestová, S. (2011). Videostudie v pedagogickém výzkumu. Brno: Paido.

Naylor, S., Keogh, B., \& Downing, B. (2007). Argumentation and primary science. Research in Science Education, 37(1), 17-39.

Nassaji, H., \& Wells, G. (2000). What's the use of triadic dialogue?: An investigation of teacher-student interaction. Applied Linguistics, 21(3), 376-406.

Potari, D., Psycharis, G., Kouletsi, E., \& Diamantis, M. (2011). Prospective mathematics teachers' noticing of classroom practice through critical events. In M. Pytlak, T. Rowland, \& E. Swoboda (Eds.), Proceedings of the Seventh Congress of the European Mathematical Society for Research in Mathematics Education (s. 2798-2807). Rzeszów: University of Rzeszów and ERME.

RVP ZV (2016). Rámcový vzdèlávací program pro základni vzdělávání. Praha: NÚV.

Rotgans, J. I., \& Schmidt, H. G. (2019). Effects of problem-based learning on motivation, interest, and learning. In M. Moallem, W. Hung \& N. Dabbagh (Eds.), The Wiley Handbook of problem-based learning (s. 157-179). Boston: Wiley.

Roth, K. J., Druker, S. L., Garnier, H. E., Lemmens, M., Chen, C., Kawanaka, T., ... Warvi, D. (2006). Teaching science in fve countries: Results from the TIMSS 1999 video study. Washington: U. S. Government Printing Office.

Savery, J. R. (2019). Comparative pedagogical models of problem-based learning. In M. Moallem, W. Hung \& N. Dabbagh (Eds.), The Wiley Handbook of problem-based learning (s. 81-104). Boston: Wiley.

Savin-Baden, M., \& Howell Major, C. (2004). Foundations of problem-based learning. McGraw-Hill Education.

Schmidt, H. G., Rotgans, J. I., \& Yew, E. H. J. (2019). Cognitive constructivist foundations of problem-based learning. In M. Moallem, W. Hung \& N. Dabbagh (Eds.), The Wiley Handbook of problem-based learning (s. 25-50). Boston: Wiley.

Selley, N. (2013). Art of constructivist teaching in the primary school: A guide for students and teachers. London: Routledge.

Simon, S., \& Richardson, K. (2009). Argumentation in school science: Breaking the tradition of authoritative exposition through a pedagogy that promotes discussion and reasoning. Argumentation, 23(4), 469.

Slavík, J., Janík, T., Najvar, P., \& Knecht, P. (2017). Transdisciplinárni didaktika: O učitelském sdilení znalostí a zvyšováni kvality výnky napríč obory. Brno: Masarykova univerzita.

Sternberg, R. (2009). Kognitivni psychologie. Praha: Portál.

Strouhal, M. (2014). O povaze pedagogické teorie aneb Jak chápat výchovné ideály. Pedagogika, 64(4), 367-382.

Šalamounová, Z., Šed’ová, K., Sedláček, M., \& Švaříček, R. (2017). Problém účelnosti v dialogickém vyučování. Pedagogika, 67(3), 247-278.

Štech, S. (2013). Když je kurikulární reforma evidence-less. Pedagogická orientace, 23(5), 615-633. 
Thuynsma, B. (2001). Caring in teaching: Critical incidents in preservice teachers' field experiences that influence their career socialization. (Unpublished dissertation). State University of New York at Albany.

Tobin, K. G. (1993). The practice of constructivism in science education. Washington, D.C.: AAA Press. Tripp, D. (2012). Critical incidents in teaching: Developing professional judgement. London: Routledge. Vaníčková, K. (2014). Transkripce v konverzační analýze. Studie z aplikované lingvistiky, 5(1), 48-64. Willbergh, I. (2015). The problems of „competence“ and alternatives from the Scandinavian perspective of Bildung. Journal of Curriculum Studies, 41(3), 334-354.

Woods-McConney, A., Wosnitza, M., \& Sturrock, K. L. (2016). Inquiry and groups: Student interactions in cooperative inquiry-based science. International Journal of Science Education, $38(5), 842-860$.

Mgr. Tereza Češková, Ph.D.

Institut výzkumu školního vzdèláváni, Masarykova univerzita;

e-mail:ceskova@ped.muni.cz

\section{ČEŠKOVÁ, T. When Potentially Developing Situations do Not Develop: Critical Didactic Incidents in Problem-oriented Instruction}

Teachers often consider the concept of competences incomprehensible and difficult to grasp in instruction. The development of pupils' competences is thus potentially limited. The study focuses on the problem-solving competence (PSC), specifically on learning situations that potentially develop pupils' PSC (i.e. problem-oriented situations with a problem task at their core). However, the fact that a teacher uses problem tasks in instruction does not automatically mean that pupils' PSC is developed.

Aim: The study aims to describe what causes the loss of the potential of problem-oriented situations to develop pupils' PSC.

Methods: 19 problem-oriented learning situations that had been identified in ten primary science lessons and were not found to actually develop PSC were researched. Using critical didactic incident analysis, concrete forms of problem-oriented learning situations are described to capture the recurrent phenomena that cause the situations to lose their potential to develop PSC.

Results: The dominant group of incidents was characterized by an excessive concentration of activity in the teacher - they guided pupils through the solving process so much that they solved the task de facto on their own. The study describes the mechanism of how this and other incidents came about. Describing some phenomena that reduce the development of PSC might help to show what should be avoided in instruction.

Keywords: problem-solving competence, critical incident, problem-oriented task, primary education, interaction. 